\title{
Jonathan R. Warner (1936-2019)—pioneer of ribosome biosynthesis
}

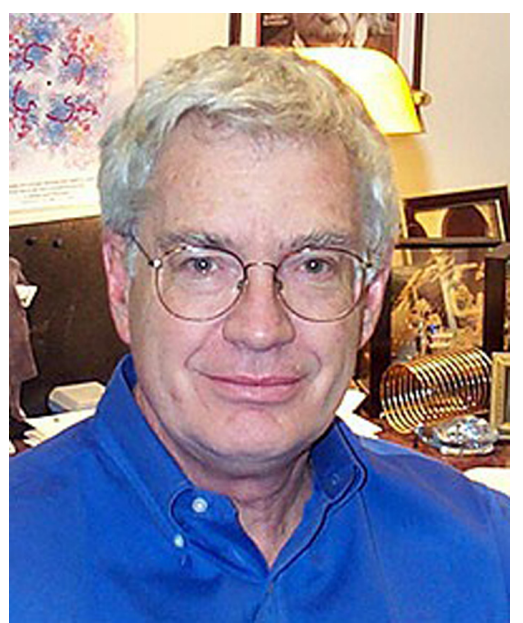

Photo reproduced by permission of the Albert Einstein College of Medicine.

This past fall, the RNA community learned of the death, on September 5, of Jonathan Warner-known by all as Jon. He was 83. A glioblastoma had been diagnosed in December 2018 and took its typically fast, tragic course.

Jon was revered as a scientist in the RNA field and equally admired as a thoughtful colleague. He was an earnest listener but never shied from providing candid input. He genuinely liked people but had a low threshold for arrogance. Jon had a penetrating scientific mind that both enabled the excellence of his work and could catch flaws in the experiments of others. He offered these latter critiques with nothing but a desire to help, being constitutionally positive, optimistic, and caring.

\section{MIT}

Jon grew up in New York City and attended Yale, majoring in Physics. He entered MIT as a graduate student, and soon found himself breaking ground in molecular biology. $\mathrm{He}$ and James Darnell added poliovirus RNA to an Escherichia coli cell-free protein synthesis system and observed some stimulation of amino acid incorporation as well as sedimentation of the RNA faster than that of single ribosomes (Darnell 1963; Warner et al. 1963a.) Jon went on the collaborate with Paul Knopf in Alex Rich's laboratory using a gently prepared lysate of rabbit reticulocytes that Irving London had developed there. Beyond the opportunity to investigate the synthesis of a specific protein, hemo- globin, it was considered likely that this was a system in which endogenous mRNA might remain intact to a greater degree than in the tissue homogenate-based protein synthesis systems previously employed. Working with an electron microscopist, Cecil Hall, Jon observed clusters of ribosomes in linear arrays (Warner et al. 1962) and published two major follow-up papers (Slayter et al. 1963; Warner et al. 1963b). The discovery of polyribosomes was so striking that many forget two other key papers of Jon's at the time, showing that the numbers of tRNAs and nascent polypeptide chains correlated with the number of ribosomes in these arrays (Warner and Rich 1964a,b)—thus all the bound ribosomes were active (something that could not have been assumed). Contemporaneously, the initial poliovirus RNA experiments were expanded by Darnell and colleagues, who demonstrated the presence of polyribosomes in both normal and virus-infected HeLa cells (Penman et al. 1963). Within only a single year, polyribosomes had come onto the landscape of molecular biology in an impressive flurry of cross-conforming studies in different systems-with Jon a key player. His work at MIT was as penetrating and transformative of that of any graduate student in biology there at the time, with perhaps one equally accomplished-a student of Boris Magasanik to whom we shall return shortly.

\section{EINSTEIN}

Jon joined Jim Darnell as a postdoc in 1963 and a year later moved with him to Albert Einstein College of Medicine. In 1965, Jon was appointed Assistant Professor. It was the beginning of 54 years at Einstein, an institution that proved perfect for him in all ways, and him monumentally perfect for it, as we shall see.

In his first years as an Assistant Professor, Jon finished and carried forward studies he and Darnell had launched on ribosomal RNA synthesis in HeLa cells, these among the first such studies (important work had been underway in both Moscow and Houston using rat liver), as well as on the relationship between translation rate and ribosome synthesis. Jon isolated nascent ribosomes from HeLa cell nucleoli (Warner and Soeiro 1967) using a key advance in the isolation of this organelle developed by Sheldon Penman, and these nascent ribosomal particles became the basis of several subsequent studies by his group, the most significant of which was the demonstration that the initial $80 \mathrm{~S}$ preribosomal particle has more proteins than 
the mature ribosomes (Kumar and Warner 1972), which foreshadowed much to come (Warner 2016).

\section{A YEAST INFECTION}

The aforementioned student of Boris Magasanik was Leland Hartwell. He and Jon overlapped at MIT for a year or so. Hartwell set up a screen in Saccharomyces cerevisiae for conditional growth mutants. Not surprisingly, this yielded mutants in ribosome synthesis. Jon and Hartwell published an extended study of these mutants (Hartwell et al. 1970) and from that moment, Jon moved his laboratory into yeast as the model system he would deploy for the rest of his career, resulting in a series of major advances. They are too numerous to cite here in detail but include the isolation and deployment of numerous additional mutants (Warner and Udem 1972), definition of the coregulation of ribosomal protein synthesis (Gorenstein and Warner 1976), the lability of new ribosomal proteins when rRNA synthesis is abrogated (Warner 1977), and the existence of a "stringent response" in yeast (Warner and Gorenstein 1978), a finding that some had not anticipated. Through the 1980s Jon and colleagues focused on translational regulation and coordination of ribosomal proteins (Pearson et al. 1982), autogenous regulation of ribosomal protein mRNA splicing (Dabeva et al. 1986), and mechanisms of Pol I promoters, initiation, and termination in numerous key papers. Jon's laboratory continued to make major advances in ribosome biosynthesis all through the 1990s and well into the new millennium.

Jon officially "retired" in 2014 but maintained an office and turned his attention to a bioinformatics/genomics project on the evolution of ribosomal proteins-proteins that must have been a determinative step as Life evolved from the RNA World. I visited him at Einstein in May 2017 and admired how engaged he was at his computer screen; I was delighted to see his animation and enthusiasm. I, of course, did not anticipate that this was to be the last time I would see him.

\section{CITIZEN}

Beyond his pioneer and enduring major contributions to the field of ribosome synthesis, Jon was exceptionally generous as a mentor and as a servant of the community of science. He served on as many study sections, editorial boards, and visiting committees as anyone I know; he was tapped for his analytical skill combined with his reputation for fair-mindedness. He was part of the group that created the RNA Society and its journal and was among several of the founders who recorded a stance that both the Society and the journal would be egalitarian. This at a time when Jon, and others, had been witnessing the editorial practices of some journals as having become destructive to the RNA community and to science in general. For example,
Jon served as the editor of Molecular and Cellular Biology for a decade and continued the tradition of fairminded reviewing and a spirit of author respect that had been instilled by the founding editor, Aaron Shatkin.

\section{ALMA MATER}

Although Jon was loyal to both Yale and MIT and served on various visiting committees, Einstein was the institutional love of his life. Beyond the fact that he served the institution longer than only a few others ever have, the duration, passion, and quality of these contributions are unexcelled. They include leading the Sue Golding Graduate division (1972-1983), serving as Chair of the Department of Cell Biology (1983-1998), and serving as Director of the School's Division of Biological Sciences (1986-1998).

\section{TWO PERSONAL REFLECTIONS}

In 1971, I had the good fortune to collaborate with one of Jon's first postdocs, Ajit Kumar. I was a postdoc in the Department of Cell Biology, upstairs from Biochemistry, and had been working on the effects of hypertonicity on RNA and protein synthesis in HeLa cells. Ajit and I decided that this would be a different way to look at the connection between protein and ribosome synthesis than the use of drugs or other experimental means. We soon wrote up a paper, gave it to Jon, and were surprised when, the next day, he said he liked it but did not want coauthorship. He saw worried expressions on our faces and immediately assured us that he was declining not because he had any issues with it, but because we had done it all on our own (Pederson and Kumar 1971). That generous moment said much about Jon, as Ajit and I also came to know in many other ways.

Much later, my laboratory discovered that the nucleolus does more than make ribosomes, including assembly of the signal recognition particle. When I told Jon about this (prepublication), he suggested caution. I was duly concerned by his reaction (and he had not seen the data), but he explained, saying that this idea was enough of a paradigm shift to be important, but that if I were wrong, my career would be over. That he would be that concerned for me, 27 years after our time at Einstein, is a telling example both of his enduring critical edge and healthy skepticism and of his care for others. He was a class act in all ways.

\section{CODA}

Jon's success in science did not imperil being a devoted husband and father, all the more reason for our admiration. He is survived by his wife of 61 years, Nancy, their daughters Anne and Deborah Warner, and four grandchildren. 
One as sterling in science and as a person comes along infrequently, and we in the RNA community have been blessed by Jon's presence in every way.

\section{ACKNOWLEDGMENTS}

I thank James Darnell and Matthew Scharff for helpful information and comments. I am supported by National Institutes of Health (NIH) grant U01 DA-040588 and the Vitold Arnett Professorship in Cell Biology.

\section{REFERENCES}

Dabeva MD, Post-Beittenmiller MA, Warner JR. 1986. Autogenous regulation of splicing of the transcript of a yeast ribosomal protein gene. Proc Natl Acad Sci 83: 5854-5857. doi:10.1073/pnas.83.16 .5854

Darnell JE. 1963. Early events in poliovirus infection. Cold Spring Harb Symp Quant Biol 27: 149-158. doi:10.1101/SQB.1962.027.001 .017

Gorenstein C, Warner JR. 1976. Coordinate regulation of the synthesis of ribosomal proteins. Proc Natl Acad Sci 73: 1547-1551. doi:10 .1073/pnas.73.5.1547

Hartwell L, McLaughlin C, Warner JR. 1970. Identification of ten genes that control ribosome formation in yeast. Mol Gen Genet 109: 4256. doi:10.1007/BF00334045

Kumar A, Warner JR. 1972. Characterization of ribosomal precursor particles from HeLa cell nucleoli. J Mol Biol 63: 233-246. doi:10 .1016/0022-2836(72)90372-5

Pearson NJ, Fried HM, Warner JR. 1982. Yeast use translational control to compensate for extra copies of a ribosomal protein gene. Cell 29: 347-355. doi:10.1016/0092-8674(82)90151-9

Pederson T, Kumar A. 1971. Relationship between protein synthesis and ribosome assembly in HeLa cells. J Mol Biol 61: 655-668. doi:10.1016/0022-2836(71)90070-2

Penman S, Scherrer K, Becker Y, Darnell JE. 1963. Polyribosomes in in normal and poliovirus-infected HeLa cells and their relationship to messenger RNA. Proc Natl Acad Sci 49: 654-662. doi:10.1073/ pnas.49.5.654

Slayter HS, Warner JR, Rich A, Hall CE. 1963. The visualization of polyribosome structure. J Mol Biol 7: 652-657.

Warner JR. 1977. In the absence of ribosomal RNA synthesis, the ribosomal proteins of HeLa cells are synthesized normally and degraded rapidly. J Mol Biol 115: 315-333.

Warner JR. 2016. Seeing is believing in ribosome assembly. Cell 166: 277-278. doi:10.1016/j.cell.2016.06.055

Warner JR, Gorenstein C. 1978. Yeast has a true stringent response. Nature 275: 338-339. doi:10.1038/275338a0

Warner JR, Rich A. 1964a. The number of soluble RNA molecules on reticulocyte ribosomes. Proc Natl Acad Sci 51: 1134-1141. doi:10 .1073/pnas.51.6.1134

Warner JR, Rich A. 1964b. The number of nascent polypeptide chains on reticulocyte polyribosomes. J Mol Biol 10: 202-211. doi:10 .1016/S0022-2836(64)80041-3

Warner JR, Soeiro R. 1967. Nascent ribosomes from HeLa cells. Proc Natl Acad Sci 58: 1984-1990.

Warner JR, Udem SA. 1972. Temperature sensitive mutants affecting ribosome synthesis in Saccharomyces cerevisiae. J Mol Biol 65: 243-257. doi:10.1016/0022-2836(72)90280-X

Warner JR, Rich A, Hall CE. 1962. Electron microscope studies of ribosomal clusters synthesizing hemoglobin. Science 138: 1399-1403. doi:10.1126/science.138.3548.1399

Warner JR, Madden MJ, Darnell JE. 1963a. The interaction of poliovirus RNA with E. coli ribosomes. Virology 19: 393-399. doi:10 .1016/0042-6822(63)90079-5

Warner JR, Knopf PM, Rich A. 1963b. A multiple ribosomal structure in protein synthesis. Proc Natl Acad Sci 49: 122-129. doi:10.1073/ pnas.49.1.122

Thoru Pederson Department of Biochemistry and Molecular Pharmacology University of Massachusetts Medical School Worcester, Massachusetts 01605, USA 


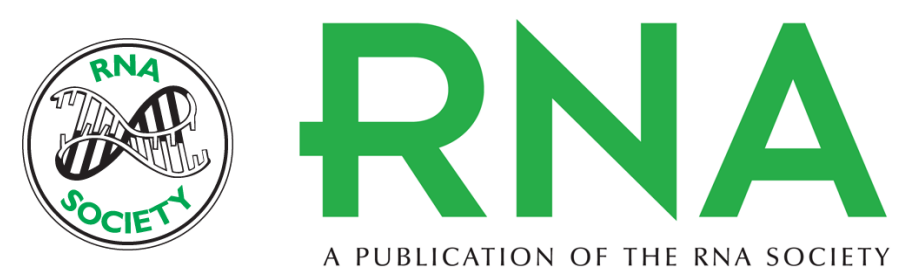

\section{Jonathan R. Warner (1936-2019)--pioneer of ribosome biosynthesis}

\section{Thoru Pederson}

RNA 2019 25: vii-ix originally published online September 18, 2019

Access the most recent version at doi:10.1261/rna.073346.119

\section{References This article cites 19 articles, 7 of which can be accessed free at: http://rnajournal.cshlp.org/content/25/12/vii.full.html\#ref-list-1}

\section{License}

Email Alerting Receive free email alerts when new articles cite this article - sign up in the box at the Service top right corner of the article or click here. 